\title{
JURISDIÇÃO ARBITRAL E EXECUÇÃO: É POSSÍVEL A EXECUÇÃO JUDICIAL DE TÍTULO EXECUTIVO EM CONTRATO QUE CONTENHA CLÁUSULA ARBITRAL?
}

\section{ARBITRAL JURISDICTION AND ENFORCEMENT: JUDICIAL ENFORCEMENT OF EXECUTIVE TITLE IN CONTRACT THAT CONTAINS ARBITRATION CLAUSE IS POSSIBLE?}

\author{
${ }^{1}$ Ana Elisa Pretto Pereira Giovanini \\ ${ }^{2}$ Jussara Suzi Assis Borges Nasser Ferreira
}

\section{Resumo}

Atualmente, prevalece no Brasil o entendimento de que a arbitragem possui natureza jurídica jurisdicional, e a sentença arbitral equipara-se à sentença judicial, sendo considerada título executivo judicial. Assim, havendo em um mesmo negócio jurídico cláusula arbitral e cláusula com eficácia de título executivo extrajudicial, analisa-se se seria necessário instaurar procedimento arbitral para a prolação de uma sentença acerca do título, ou se este poderia ser executado diretamente no juízo estatal.

Palavras-chave: Jurisdição Arbitral; execução de sentença arbitral; cláusula arbitral; título executivo extrajudicial.

\begin{abstract}
Currently prevails in Brazil the understanding that the arbitration court has national legal, and the award equates to the court judgment, considered judicial enforceable. Thus, with arbitration clause and clause containing enforceable efficiency within a legal business, it is analyzed whether it was necessary to resort to arbitration to have a sentence, or if the title could be executed directly in state court.
\end{abstract}

Keywords: Arbitration Jurisdiction; award of execution; arbitration clause; extrajudicial executive title

\footnotetext{
${ }^{1}$ Mestranda em Direito Processual Civil, na Universidade Paranaense, UNIPAR - PR, (Brasil). Advogada. Email: anaelisa@yokohamaegiovanini.com.br.

${ }^{2}$ Doutora pela Pontifícia Universidade Católica de São Paulo, PUCSP- SP, (Brasil). Docente do Programa de Mestrado em Direito da Universidade de Marília, UNIMAR - SP, (Brasil),e do Programa de Mestrado em Direito Processual e Cidadania da Universidade Paranaense, UNIPAR - PR, (Brasil). E-mail: jussara@bflaw.adv.br
} 


\section{INTRODUÇÃO}

Com origem anterior à jurisdição estatal ${ }^{3}$, em seus primórdios, a arbitragem não dependia da intervenção do Estado, pois os envolvidos no litígio elegiam um terceiro de confiança que fosse capaz de apontar uma solução ao conflito que deveria, impreterivelmente, ser cumprida pelas partes. Trata-se, ainda hoje, de meio heterocompositivo ${ }^{4}$ de resolução de conflitos, pois se confia a esse terceiro imparcial a solução ao problema apresentado.

Ao longo da história, não houve uma evolução linear e abrupta da arbitragem para a solução de controvérsias em âmbito estatal. Tanto a jurisdição estatal quanto a arbitragem coexistiram na maior parte do tempo, havendo prevalência de uma com relação à outra em períodos esparsos. Embora o volume de processos seja mais expressivo na jurisdição estatal, o que parece denotar sua prevalência em detrimento das câmaras arbitrais, há determinadas espécies de contratos cujas controvérsias são mais bem resolvidas em âmbito arbitral, especialmente em razão da tecnicidade da causa ${ }^{5}$. Ainda, há sistemas jurídicos estrangeiros nos quais determinados conflitos são obrigatoriamente submetidos ao juízo arbitral ${ }^{6}$.

Cumpre salientar que não se trata a arbitragem de meio alternativo de resolução de conflitos, tampouco objetiva desafogar o Judiciário ao abarcar para si questões que também poderiam ser resolvidas neste Poder. Em que pese haja situações nas quais o procedimento e a sentença arbitral sejam praticamente idênticos aos do juízo estatal, outras apresentariam elevado grau de dificuldade para que fossem resolvidas com êxito perante o juízo estatal. Assim, a arbitragem é apenas um modo de resolução de conflitos, estabelecida por meio de

\footnotetext{
${ }^{3}$ CARMONA, C. A. Arbitragem e jurisdição. Revista dos Tribunais On Line. p. 1. Revista de Processo | vol. 58 | p. 33 - 40 | Abr - Jun / 1990. Doutrinas Essenciais Arbitragem e Mediação | vol. 1 | p. 833 - 844 | Set / 2014. DTR $1990 \backslash 55$. p 01.

${ }^{4}$ Historicamente, a doutrina classifica os meios de composição de litígio em três espécies, que são a autotutela, a autocomposição e a heterocomposição. Ocorrerá a autotutela quando a solução do conflito de interesses se der pela imposição da vontade de uma das partes, em detrimento do interesse da outra. Já a autocomposição é a forma de solução de conflitos na qual uma das partes ou ambas cedem parte de seus interesses, ou mesmo todo seu interesse, em função do interesse do outro. Acerca do assunto, vide Fredie Didier Jr. Curso de Direito Processual Civil: teoria geral do processo e processo de conhecimento. 13a ed. v.1. Bahia: Editora JusPodivm, 2010. p. 99-100.

${ }^{5}$ Ensina Manuel Pereira Barrocas, que a arbitragem é também utilizada para "dirimir questões de natureza técnica, sem conteúdo jurídico, para cuja intervenção os tribunais judiciais não têm competência - é o caso da arbitragem sobre a qualidade técnica de uma coisa, independentemente de qualquer efeito jurídico relativo à controvérsia". Contudo, comenta que nessa espécie de controvérsia não é fácil admitir que se estivesse na presença da verdadeira arbitragem. Manual de Arbitragem. Coimbra: Editora Almedina. 2010, p. 34.

${ }^{6}$ CARMONA, C. A. Ob. cit. p.01.
} 
convenção entre as partes, que atribuem a um ou mais juízes arbitrais o poder de decidir aquela questão que, geralmente, demanda alto conhecimento técnico a respeito de seu objeto ${ }^{7}$.

Em que pese haja total independência entre a atividade jurisdicional arbitral e a atividade jurisdicional estatal - exceto no que se refere à execução da sentença arbitral, que ainda depende da atuação estatal, caso não cumprida voluntariamente pelo vencido - surgem, diariamente, dúvidas a respeito de situações que não possuem respaldo legal explícito. A problematização do estudo vincula-se a uma dessas questões; refere-se ao descumprimento de uma cláusula contratual com força de título executivo extrajudicial contida em contrato que também possuía cláusula arbitral para a resolução de quaisquer celeumas oriundas daquele contrato.

Diante do ocorrido e da ausência de respaldo legal expresso, precedente jurisdicional ou de uma tese doutrinária que solucionasse a questão, surgiu a perquirição, e na qual reside o objeto de investigação do estudo, se seria necessário instaurar procedimento arbitral para que fosse proferida uma sentença arbitral, a ser posteriormente executada perante o órgão jurisdicional estatal, ou se seria possível tão somente e imediatamente executar perante a justiça estatal mencionada cláusula, que possuía obrigação líquida, certa e exigível.

Assim, para a compreensão do fundamento jurídico que levou à resolução de mencionada celeuma, demonstrou-se ao longo deste artigo os entendimentos a respeito da natureza jurídica da arbitragem e sua atividade jurisdicional, elementos essenciais para que seja possível compará-la e confrontá-la com a atividade jurisdicional estatal, o que contou com levantamento bibliográfico dentre os principais autores que tratam do tema. Analisou-se, do mesmo modo, a sentença arbitral e sua execução, e, por fim, a questão da execução judicial ou não da cláusula com eficácia de título executivo extrajudicial em negócio jurídico que contém cláusula arbitral.

\footnotetext{
${ }^{7}$ Interessante comparativo com relação à arbitragem no Brasil é o traçado por doutrinadores Norte Americanos ao versarem sobre as diferenças entre um Tribunal Arbitral e a Corte Nacional americana. Dentre as diferenciações trazidas pelos autores, destaca-se o principal fator diferenciador entre a Corte Nacional e um Tribunal Arbitral, que seria "the rigidity of national court procedures. Whichever court one goes t, inevitably, there are civil procedural rules or codes or precedent as to the way in which cases are conducted. The procedural rules or code lay down the basis for the courts' jurisdiction, the circumstances in which an action can be brought, which particular national court has jurisdiction over a particular type of dispute, how to initiate proceedings, what documents must be filed, the rights of reply and how the case, generally, should be conducted. There are little or no areas on wich the judge can, in his discretion, even with the agreement of the parties, move away from scritures od the civil procedure rules or code". LEW, Julian D.M. MISTELIS, Loukas A. KROL, Stefan M. Comparative International Commercial Arbitration. Klwer Law International: Netherlands, 2003. p. 5.
} 
Para tanto, no que se refere à seleção metodológica, a problematização permaneceu como opção permanente, vinculada à sistematização, considerando a necessidade determinada pelo próprio eixo temático, em si, uma questão problema. Na sequência, foi utilizado pesquisa bibliográfica e jurisprudencial, com objetivo exploratório e explicativo,de abordagem teóricobibliográfico, empregando-se como instrumento para a dissecção do tema pesquisado a natureza jurídica da arbitragem e a execução de títulos que contenham cláusula arbitral.

\section{NATUREZA JURÍDICA DA ARBITRAGEM}

Encontrar o núcleo essencial do objeto a ser estudado a fim de que se defina sua natureza jurídica é tarefa complexa e que, no caso da arbitragem, exige a revisão do conceito de jurisdição e a análise crítica do antigo paradigma da dicotomia público-privado. Ademais, necessária a compreensão da natureza jurídica da convenção de arbitragem, que é anterior à arbitragem em si. Traça-se, a seguir, um breve esboço acerca das teorias cujo objeto consiste na definição da natureza jurídica da arbitragem.

Primeiramente, no que concerne à convenção de arbitragem, cumpre destacar que, uma vez que para a instauração do procedimento arbitral faz-se necessária a existência de convenção de arbitragem, tal circunstância demonstra sua natureza de negócio jurídico, pois decorre de acordo entre as partes. Contudo, segundo Manuel Pereira Barrocas, a convenção de arbitragem não seria negócio jurídico processual, mas "negócio jurídico cujo primeiro efeito típico é a atribuição à lei reguladora da arbitragem de um determinado Estado de competência para regular a arbitragem pretendida pelas partes"8.

Não possuindo, portanto, natureza processual, a convenção de arbitragem constitui "negócio jurídico de natureza substantiva, não processual, embora instrumental ou de meio de obtenção de um outro efeito jurídico - a resolução de um litígio objecto de uma outra relação jurídica"9.

Em que pese não haja maiores discussões quanto à natureza jurídica da convenção de arbitragem, a natureza jurídica arbitragem em si ainda é objeto de inúmeras discussões, de modo que inexiste consenso doutrinário a esse respeito.

Profundos debates acerca da natureza jurídica da arbitragem surgiram nos primórdios do século XX, cujo marco inicial foi decisão prolatada pela Corte de Apelação de Paris, no

\footnotetext{
${ }^{8}$ BARROCAS, M. P. Ob. cit. p. 41

${ }^{9}$ Idem. p. 42.
} 
caso Del Drago, em 10 de dezembro de 1901, segundo a qual um laudo arbitral estrangeiro equivaleria a uma sentença estrangeira, o que implicaria conferir à decisão arbitral caráter jurisdicional ${ }^{10}$.

Em virtude da ausência de consenso a respeito da natureza jurídica da arbitragem, se tratar-se-ia de espécie de jurisdição ou não, são quatro teorias que objetivam definir sua natureza jurídica, quais sejam: a teoria jurisdicionalista, a teoria contratualista, a teoria mista e a teoria autonomista.

a) Teoria Jurisdicionalista

Essa corrente assenta seu entendimento no fato de que o Estado, por meio da lei, permite e regula a prática da arbitragem, de modo que esta somente existe e é reconhecida por determinação legal. O sustentáculo inicial dessa teoria está na famosa sentença prolatada pela Cour d'appel de Paris, em 10 de dezembro de 1901, no caso Del Drago, que decidiu que o laudo arbitral estrangeiro equivaleria à sentença judicial estrangeira, o que conferiu caráter jurisdicional à arbitragem.

Em virtude do poder de julgar conferido ao árbitro, somado à eficácia jurídica atribuída à decisão arbitral, os árbitros estariam a desempenhar função pública recebida diretamente pela lei. Contudo, embora juiz estatal e juiz arbitral recebam seu poder diretamente do exercício do Poder Soberano do Estado - lei -, o árbitro pode ser nomeado pelas partes, ao passo que o juiz não o pode ${ }^{11}$.

Para essa corrente, portanto, o exercício da função jurisdicional não seria exclusivo do Estado, pois passível de ser desempenhado por agentes privados. Isso não significa que se está a romper com o conceito de que a jurisdição é monopólio do Estado. A jurisdição é, sim, monopólio do Estado, mas o seu exercício não o é, pois pode o Estado autorizar o exercício da função jurisdicional por meio de outros meios que não apenas o Poder Judiciário ${ }^{12}$

Outro argumento que respalda essa teoria é o fato de a sentença arbitral só poder ser revisada pelo Poder Judiciário quanto a aspectos atinentes à sua validade, e jamais com relação ao seu mérito, o que demonstra a soberania da decisão arbitral. Acresce-se a isso o

\footnotetext{
${ }^{10}$ Cour d1appel Paris, 10 de Dezembro de 1901, 29 Clunet 314 in LEW, J. D.M. MISTELIS, L. A., KROL, S. M. op. cit. p. 76.

${ }^{11}$ BARROCAS, M. P.. Op. cit. p. 43.

${ }^{12}$ DIDIER JR, F. Op. cit p. 92.
} 
fato de que para que produza efeitos, a sentença arbitral estrangeira deverá apenas passar por procedimento de homologação perante o Superior Tribunal de Justiça, não sendo analisado seu mérito, mas tão somente sua validade.

Argumento levantado pelos contrários a essa teoria consiste em limitação decorrente da impossibilidade de o árbitro efetuar a execução da sentença caso não haja seu cumprimento voluntário. Nessa seara, os adeptos à teoria jurisdicional refutam citado entendimento com respaldo no argumento de que isso não excluiria da arbitragem sua natureza jurisdicional, pois tal circunstância implica apenas limitação ao exercício da atividade do árbitro, o que pode ser imputado a qualquer procedimento por expressa disposição legal ${ }^{13}$.

Outra questão aqui debatida é a alegada renúncia feita à jurisdição quando se opta pela arbitragem. Segundo essa corrente jurisdicionalista, não há falar em renúncia à jurisdição, eis que as partes apenas deixam de utilizar-se da jurisdição estatal em adoção à jurisdição arbitral, ou seja, não há qualquer renúncia à jurisdição, pois apenas se utiliza um meio diverso do outro. A esse respeito, destaca-se escólio de Manuel Pereira Barrocas ${ }^{14}$, segundo o qual

\begin{abstract}
A arbitragem já não é hoje um meio de retirar competência dos tribunais e, assim, a convenção de arbitragem não constitui um negócio jurídico processual dentro dos estreitos limites dos conceitos jusprocessualistas nacionais de um Estado. A arbitragem, quer doméstica, quer internacional, constitui uma instituição autônoma de resolução de litígios, que não é um substituto dos tribunais judiciais. Tem princípios, regras e metodologia próprios.
\end{abstract}

No Brasil, os artigos 18 e 31 da Lei 9.307/96 (Lei de Arbitragem), corroboram a presente teoria na medida em que determinam ser o árbitro juiz de fato e de direito, assim como sua sentença não se sujeitar a recurso ou homologação pelo Poder Judiciário, e possuir a mesma eficácia da sentença judicial, constituindo-se título executivo judicial. Nessa perspectiva, "o novo procedimento arbitral, uma vez instaurado, em tudo se equipara à jurisdição oficial"15.

Joel Dias Figueira Junior afirma que a arbitragem possui natureza jurisdicional; e mais, entende que se trata de "verdadeira jurisdição de caráter privado. Aliás, o novo microsistema que contempla o juízo arbitral não permite, ao nosso entender, outra conclusão" ${ }^{16}$.

Também nessa perspectiva, afirma Nelson Nery Junior ${ }^{17}$ que

\footnotetext{
${ }^{13}$ Nesse sentido, vide FIGUEIRA JUNIOR, J.D. op.cit. p. 156-157.

${ }^{14}$ Idem, p.41/42

15 THEODORO Jr. H. Curso de Direito Processual Civil. Rio de Janeiro: Forense, v. III, 2005, p.115.

${ }^{16}$ FIGUEIRA JUNIOR, J. D. op. cit. p. 157.
} 


\begin{abstract}
A natureza jurídica da arbitragem é de jurisdição. O árbitro exerce jurisdição porque aplica o direito ao caso concreto e coloca fim à lide que existe entre as partes. A arbitragem é instrumento de pacificação social. Sua decisão é exteriorizada por meio de sentença, que tem qualidade de título executivo judicial, não havendo necessidade de ser homologada pela jurisdição estatal.
\end{abstract}

Segundo essa teoria, portanto, a natureza jurisdicional da arbitragem estabelece-se, fundamentalmente, na atividade exercida pelo árbitro e no objetivo de pacificação social, sendo este, segundo os jurisdicionalistas, o objetivo maior tanto da jurisdição estatal quanto da jurisdição arbitral.

\title{
b) Teoria Contratualista
}

$\mathrm{O}$ argumento de base dessa corrente se respalda do fato de que a arbitragem advém de pactuação realizada livremente pelos contratantes, a qual define todos os aspectos do futuro procedimento que poderá vir a ser instaurado. Isso lhe conferiria natureza contratual.

Essa teoria foi formulada em virtude do julgamento do caso Roses, pela Cour de Cassation, em Paris ${ }^{18}$. Restou decidido em mencionado caso que os laudos arbitrais se baseariam na convenção de arbitragem, com a qual constituiria uma unidade, razão pela qual a arbitragem compartilharia a natureza contratual da convenção.

Assim, "todo o processo, a sua razão de ser, a sua fonte ou origem, bem como a nomeação do árbitro, as próprias regras do processo e o direito aplicável, tudo reside ou tem origem na vontade das partes"19. O Estado não teria qualquer controle sobre a arbitragem e a decisão arbitral, de modo que tão somente deteria o poder de executar a sentença, caso não cumprida espontaneamente pela parte vencida.

Forte argumento dessa teoria reside no entendimento de que o exercício da jurisdição seria exclusivo do Estado, que teria o poder de delegá-lo apenas aos magistrados, pois submetidos e aprovados em concurso público. Por essa razão, o árbitro não poderia ser igualmente considerado magistrado apenas pelo fato de exercer atividade semelhante.

\footnotetext{
${ }^{17}$ Código de Processo Civil Comentado. 3a ed. São Paulo: Revista dos Tribunais, 1997. p. 1300.

${ }^{18}$ Cour de Cassation, 27 de julho de 1937. Roses vs Moller et Cie. Dalloz, vol I, p. 25.in BARROCAS, M. P. op. cit. p. 42.

${ }^{19}$ BARROCAS, M. P. op. cit. p. 43.
} 
Além disso, estudiosos clássicos como Chiovenda e Carnelutti ${ }^{20}$ entendiam que a jurisdição tinha por escopo dar efetividade aos preceitos contidos na norma de direito material, e apenas o juiz possuiria o efetivo compromisso com a lei em sua aplicação ao caso concreto. Entendia-se que o árbitro não possuía tal compromisso, estando alheio a esse rigorismo. "Nessa óptica, o que valia como ponto de referência era o cumprimento dos preceitos de direito material, particularmente aqueles contidos no ordenamento jurídicopositivo do País"21.

Nessa linha, o árbitro não possuiria diversos dos poderes jurisdicionais, como a condução coercitiva de testemunhas, assim como os demais atos que são inerentes ao exercício da jurisdição e conferidos ao magistrado. Com isso, invoca essa teoria que o marco distintivo entre o procedimento arbitral e jurisdicional seria a execução da decisão, pois o poder de império seria exclusivo do magistrado.

Para Cândido Rangel Dinamarco e Bruno Vasconcelos Lopes, adeptos à teoria contratualista, a atividade jurisdicional é exclusiva do Estado, vez que a jurisdição é "expressão do poder estatal, exercida com a função de pacificar e mediante as atividades disciplinadas pela Constituição e pela lei"22. Trazem, portanto, como conceito de jurisdição estatal a "função do Estado, destinada à solução imperativa de conflitos e exercida mediante a atuação da vontade do direito em casos concretos"23.

Com o advento da Lei 13.129/15 - que trouxe importantes mudanças à lei da arbitragem -, introduziu-se à seara arbitral um mecanismo de cooperação entre o poder judiciário e a justiça arbitral, denominado carta arbitral. Por meio deste mecanismo, é dada ao juiz arbitral a possibilidade de executar, com o auxílio do poder judiciário, medidas cujo mandamus é de competência exclusiva do juiz togado.

Ao argumento dos adeptos da teoria jurisdicional de que a arbitragem seria instrumento de pacificação social, a corrente contratualista rebate sustentando que esse termo seria genérico e não refletiria a essência da jurisdição. A pacificação social, segundo esse entendimento, não decorreria apenas e tão somente de uma decisão justa, assim como

\footnotetext{
${ }^{20}$ A respeito do pensamento desses autores e críticas, vide comentários ao art. 16, em obra de José Miguel Garcia Medina. Novo Código de Processo Civil comentado: com remissões e notas comparativas ao CPC/1973. São Paulo: Editora Revista dos Tribunais, 2015. p. 75-76.

${ }^{21}$ DINAMARCO, C.R.. A arbitragem na teoria geral do processo. São Paulo: Editora Malheiros. 2013. p. 38.

${ }^{22}$ DINAMARCO, C.R.. LOPES, B. V. C.. Teoria geral do novo processo civil. São Paulo: Editora Malheiros. 2016. p. 77.

${ }^{23}$ Idem. p. 78
} 
"inúmeras atividades privadas podem conduzir à pacificação social e que ninguém jamais ousou qualificá-las como jurisdicionais somente por esse motivo". ${ }^{24}$

A similaridade entre os processos judicial e arbitral também não poderia ser utilizado como argumento identificador de ambos, pois a arbitragem seria inteiramente privada, paga pelas partes e influenciada por fatores alheios, e o processo judicial obrigatoriamente segue procedimento estabelecido por lei, esta criada e promulgada por indivíduos democraticamente eleitos, e cuja sentença é prolatada por sujeito submetido e aprovado via concurso público.

c) Teoria Mista ou Híbrida.

A teoria mista foi criada ${ }^{25}$ pelo Professor Sauser-Hall, no ano de 1952, em um relatório que apresentou ao Institut Droit International ${ }^{26}$. Nesse relatório, mencionado Professor sustentou que o laudo arbitral não poderia ser independente da legislação interna, razão porque necessária uma lei interna que norteasse a cláusula compromissória e sua execução. Além disso, reconheceu ser a arbitragem oriunda de pactuação entre particulares que, além da escolha do árbitro, submetem-no à legislação também por eles escolhida. Assim, teria a arbitragem um caráter jurisdicional e contratual.

Essa teoria combina, portanto, as duas anteriores, vindo a conferir à arbitragem uma concepção mais adequada à sua realidade atual sob uma perspectiva internacional, eis que em conformidade com a Lei Modelo da UNCITRAL (United Nations Commission on International Trade Law), a qual fora criada com o objetivo de harmonizar as leis arbitrais dos diversos países sob uma perspectiva global.

O Brasil não adotou a Lei Modelo da UNCITRAL integralmente para a elaboração da Lei 9.307/96 - Lei da Arbitragem. Contudo, inspirou-se nalguns dispositivos dessa Lei Modelo para a elaboração de referida lei federal.

\footnotetext{
${ }^{24}$ MARINONI, L. G. Rápidas observações sobre arbitragem e jurisdição. 2014. p.14-24. Disponível em <https://processoemdebate.files.wordpress.com/2010/09/arbitragem-e-jurisdicao_marinoni.pdf〉. Acesso em 15 de agosto de 2016. p. 20

${ }^{25}$ Diversamente do exposto, segundo Manuel Pereira Barrocas, em obra citada, p. 45, essa tese teria sido criada por Henri Molutsky, em sua obra Études et notes sur l'arbitrage, Ecrits, vol II. Dalloz, Paris, 1974, o qual teria sintetizado a natureza jurídica da arbitragem, salientando o caráter contratualista da sua fonte, mas a função jurisdicional da sua finalidade. Contudo, optou-se por manter a originalidade da obra ao Professor Sauser-Hall em razão das datas trazidas pelos doutrinadores citados, eis que neste, constata-se ter sido criada a teoria em 1952, anteriormente, portanto, à de 1974, de Henri Molutsky.

${ }^{26}$ LEW, J. D.M., MISTELIS, L. A., KROL, S. M. Op. cit. p. 79
} 
Segundo a teoria mista, portanto, a arbitragem abarca elementos tanto da teoria jurisdicionalista quanto da teoria contratualista Isso porque a convenção de arbitragem, em virtude de sua natureza contratual, é imprescindível para que seja possível a instauração do procedimento arbitral. Do mesmo modo, necessárias as normas jurídicas processuais para o desenrolar do procedimento arbitral. Nesse sentido, segundo Manuel Pereira Barrocas ${ }^{27}$

Para essa tese, a arbitragem aglutina elementos da tese jurisdicionalista e da tese contratualista. Da segunda, porque considera que, sem a convenção de arbitragem, não existe verdadeira arbitragem. Da primeira porque, sem elementos de direito público, a arbitragem dificilmente funcionaria e seria eficaz, tais como a força de caso julgado da sentença arbitral, o reconhecimento de que os árbitros exercem uma função jurisidicional e que a sentença por eles proferida tem o mesmo valor jurídico de uma sentença de um tribunal judicial.

No plano internacional há predominância dessa teoria, vez que mescla os conceitos das teorias contratual e jurisdicional, espelhando, na prática, a realidade econômica e sociológica da arbitragem comercial internacional.

\section{d) Teoria Autônoma}

A teoria autônoma ou autonomista é uma leitura distinta das três teorias anteriores, firmando-se no caráter independente da arbitragem frente ao Estado, tratando-se, portanto, de procedimento autônomo e sui generis.

Essa teoria foi criada por Jacqueline Rubellin-Devichi, no ano de 1965, sob o argumento de que a arbitragem deve ser estudada segundo seus objetivos e forma ${ }^{28}$. Segundo essa teoria, a arbitragem funcionaria independentemente da legislação nacional, o que reforçaria a ideia de que a arbitragem não possuiria uma nacionalidade específica, aplicandose a ela apenas as normais transnacionais do direito.

Assim, não importaria o local onde foi pactuada a arbitragem, bem como o poder dos árbitros derivaria exclusivamente da vontade das partes contratantes, não se submetendo à legislação nacional e à soberania do Estado onde pactuada.

Embora aplicável em países mais progressistas, como França e Estados Unidos, essa teoria não é aplicável no território brasileiro, pois o ordenamento jurídico nacional determina que as sentenças arbitrais internacionais devem ser homologadas pelo Superior Tribunal de

\footnotetext{
${ }^{27}$ Op. cit. p. 44 ..

${ }^{28}$ LEW, J. D.M., MISTELIS, L. A., KROL, S. M. Op. cit. p.. p. 81
} 
Justiça para que produzam efeitos. A legislação brasileira, portanto, é relevante, para que a sentença estrangeira aqui produza efeitos.

e) Teoria adotada majoritariamente no Brasil.

Embora a doutrina nacional se divida entre as teorias contratual e jurisdicional, atualmente, prepondera o entendimento de que a arbitragem se manifesta como exercício de atividade jurisdicional, pois prevalece o fundamento da pacificação dos litigantes mediante a resolução do conflito que os envolve. Ademais, ao ser equiparada à sentença judicial, a sentença arbitral acaba por mostra-se um reflexo da natureza jurisdicional da arbitragem ${ }^{29}$.

$\mathrm{Na}$ seara jurisprudencial, a orientação é no sentido de que a natureza jurídica da arbitragem é jurisdicional, especialmente porque sua sentença constitui título executivo judicial, embora necessária a execução desse título pelo juízo estatal. Com isso, observa-se que "o juízo arbitral não substitui, integralmente, a atividade jurisdicional estatal. Mesmo a execução de sentença arbitral depende do Poder Judiciário. O monopólio estatal, assim, recai sobre a tutela coativa dos direitos $[\ldots]^{\prime \prime 30}$.

Extrai-se disso que a jurisdição não seria definida pelos sujeitos que a realizam, mas pela natureza e escopo da atividade que está sendo exercida. Assim, "o que importa e se impõe como elemento essencial é o escopo social da pacificação"31. E, por esse motivo, pouco importaria "o poder do árbitro ter origem na convenção das partes, e não na Constituição ou na lei, e de a execução forçada estar inteiramente excluída de suas atividades" ${ }^{32}$. Nessa linha, ensina Carlos Alberto Carmona ${ }^{33}$ que

O fato de encarar-se a jurisdição como poder, atividade e função do Estado não descaracteriza, desde logo, a jurisdicionalidade da arbitragem. Trata-se, evidentemente, de participação do povo na administração da justiça - o que não afronta o art. $153, \S 4 .^{\circ}$, da Constituição Federal e encontra respaldo no seu $\S 1 .^{\circ}$ do artigo $1 .{ }^{\circ}$. Basta lembrar, em reforço a tal argumentação, que a instituição do júri, mantida no mesmo artigo 153 da Constituição Federal, é baluarte da participação popular a nível jurisdicional.

Importante salientar que a jurisdição arbitral também é exercida com fundamento em um poder que - diferentemente da jurisdição estatal, cujo poder é fundado no poder de

\footnotetext{
${ }^{29}$ DINAMARCO, C. R. Op. cit. p. 39.

${ }^{30}$ MEDINA. J.M.G. Op. cit. p. 77.

${ }^{31}$ Idem. p. 41.

${ }^{32}$ Idem. Ibidem.

${ }^{33}$ CARMONA, C. A. Op. cit. p. 01.
} 
império soberano do Estado - tem sua fonte no poder oriundo da vontade unilateral das partes que optaram pela arbitragem - autonomia da vontade. A vontade das partes é, portanto, imprescindível para a instauração do procedimento arbitral, e acerca do qual a nenhuma delas "será lícito recusar-se a esse procedimento ou furtar-se ao cumprimento do que ali vier a ser decidido" 34 , afinal, sua instituição decorreu de um acordo de vontades.

Assim, permanece o entendimento de que a jurisdição é monopólio do Estado, contudo, seu exercício não está adstrito ao Poder Judiciário, especialmente porque embora sejam notórias as diferenças entre o procedimento judicial e o procedimento arbitral, estas não são capazes de excluir a jurisdição arbitral do conceito de jurisdição, especialmente pelo fato de que o escopo de ambas é o mesmo, qual seja, a pacificação social e a segurança jurídica ${ }^{35}$. Prevalece atualmente, portanto, a teoria na natureza jurídica jurisdicional da arbitragem.

\section{SENTENÇA ARBITRAL E SUA EXECUÇÃO}

Realizado o regular procedimento arbitral, este finalizará com uma sentença cuja eficácia legalmente prevista é de título executivo judicial. Por essa razão, caso não seja voluntariamente cumprida pelo vencido, deverá ser levada a juízo estatal para a promoção de sua execução, por meio da qual se efetivarão os direitos reconhecidos pela sentença arbitral.

No ano de 1958, em Nova Iorque, realizou-se na sede da ONU uma Convenção que tratou do reconhecimento e da execução das decisões arbitrais estrangeiras. Esse foi considerado o acordo multilateral de maior importância no âmbito do Direito Arbitral Internacional, cuja ratificação, hoje, ultrapassa 130 países.

Essa convenção requereu que se fizesse valer o reconhecimento dos contratos por escrito de arbitragem internacional; a recusa quanto à permissão de uma disputa litigiosa entre as partes quando essa discussão estaria sujeita à cláusula arbitral; e o reconhecimento e a execução das decisões arbitrais proferidas em território diverso daquele que se busca o reconhecimento e a execução de mencionadas decisões ${ }^{36}$.

Apenas no ano de 2002, por meio do Decreto 4.311, promulgou-se no Brasil a Convenção de Nova Iorque, o que o sublevou ao rol dos países mais avançados no mundo

\footnotetext{
${ }^{34}$ DINAMARCO, C. R.. LOPES, B. V. C.. Op. cit. p. 80.

35 A respeito dos escopos da jurisdição, vide DINAMARCO, C. R. A instrumentalidade do processo. São Paulo: Editora Malheiros. 2013. p. 177-263.

36 A esse respeito, vide a Convenção Sobre o Reconhecimento e a Execução de Sentenças Arbitrais Estrangeiras feita em Nova York, em 10 de junho de 1958, anexa ao Decreto ${ }^{\circ} 4.311$, de 23 de julho de 2002, que contém o procedimento para o reconhecimento e a execução da sentença arbitral estrangeira.
} 
acerca de Direito Arbitral. Essa medida permitiu que fossem reconhecidas as decisões arbitrais estrangeiras em território brasileiro; que fossem homologadas e executadas as sentenças arbitrais nacionais no exterior sem a necessidade de ajuizamento de ação perante o Poder Judiciário do país estrangeiro signatário da Convenção; e que as sentenças arbitrais com partes brasileiras possam vir a ser executadas em território nacional e em território estrangeiro.

Em consonância com mencionado Decreto, a Lei 9.307/96, em seu art. 34, determinou que "a sentença arbitral estrangeira será reconhecida ou executada no Brasil, de conformidade com os tratados internacionais com eficácia no ordenamento interno e, na sua ausência, estritamente de acordo com os termos desta Lei".

Assim, para que as sentenças arbitrais estrangeiras produzam efeitos no Brasil, devem ser submetidas à chancela do Superior Tribunal de Justiça, consoante dispõe o art. 35, da Lei 9.307/96 - Lei da Arbitragem). Por outro lado, tal procedimento é dispensado às sentenças arbitrais proferidas em território nacional, pois estas equiparam-se de plano às sentenças judiciais, motivo pelo qual são consideradas título executivo judicial, por força do disposto no art. 515, VII, do novo Código de Processo Civil.

Ao serem homologadas pelo Superior Tribunal de Justiça, as sentenças arbitrais estrangeiras equiparam-se às sentenças arbitrais nacionais, e também passam a ser consideradas título executivo judicial, motivo pelo qual seguirão o mesmo procedimento de execução das sentenças arbitrais nacionais, com a diferença de que o foro competente é o da Justiça Federal.

Assim como as sentenças arbitrais nacionais, as internacionais também não podem ter seu mérito analisado pelo poder judiciário. A partir do momento que a sentença arbitral estrangeira é homologada e que não é mais possível a interposição de recurso em face da sentença arbitral nacional, ambas fazem coisa julgada formal e material, sendo passíveis de execução mediante cumprimento de sentença ${ }^{37}$.

Na hipótese, portanto, de não haver o cumprimento voluntário da sentença arbitral, será necessário executá-la perante o juízo estatal, cujo apoio decorre de cooperação legalmente prevista entre a justiça estatal e a justiça arbitral. Além da cooperação para a execução da sentença arbitral perante o juízo estatal, há diversas situações nas quais não é

${ }^{37}$ Nesse sentido, vide Francisco J. C. Curso de Arbitragem. 5a ed. rev. e atual., de acordo com a Lei 13.129/2015, com a Lei 13.140/2015 e o Novo CPC. São Paulo: Editora Revista dos Tribunais. 2015. p. 341 
conferido ao juiz arbitral poder para o exercício desse mandamus, como execução de tutelas cautelares e de urgência ${ }^{38}$, condução de testemunhas renitentes e execução de carta $\operatorname{arbitral}^{39}$.

\section{EXECUÇÃo de TítUlo EXECUTIVO EM CONTRATO QUE CONTÉM CLÁUSULA ARBITRAL}

O processo de execução possui capítulo próprio no Código de Processo Civil, sendo considerado espécie de ação. Atualmente, o processo de execução tem por objetivo prestar a tutela satisfativa dos direitos reconhecidos nos títulos executivos extrajudiciais, os quais prescindem de todo um processo de conhecimento anterior para demonstrar o direito nele expresso.

A questão controvertida, aqui, surgiu com o advento de cláusulas com caráter de título executivo extrajudicial, mas em cujo negócio também esteja contida cláusula compromissória. Levou-se ao Poder Judiciário a discussão se seria possível executar esse título no que tange à sua cláusula com natureza de título executivo extrajudicial, mesmo possuindo esse cláusula arbitral, ou se necessária a instauração de procedimento arbitral para que fosse prolatada uma sentença arbitral executável perante juízo estatal.

Também questionou-se se, ao ingressar-se imediatamente com procedimento executivo de mencionada cláusula com caráter de título executivo extrajudicial, tal circunstância possibilitaria a discussão do mérito da dívida em sede de defesa do executado, mesmo se no negócio originário estiver contida cláusula arbitral.

A questão tramitou a ponto de ser submetida ao Superior Tribunal de Justiça que, feita a análise pormenorizada do caso e desenvolvidos sólidos argumentos para sustentar sua tese, entendeu a Corte Superior ser perfeitamente possível a execução de mencionada cláusula sem que fosse necessária a instauração do procedimento arbitral. Contudo, necessário que referida cláusula contenha dívida líquida, certa e exigível.

Todo documento particular assinado pelo devedor e por duas testemunhas, consoante dispõe o art. 784, do CPC, possui força executiva, pois classificado como título executivo extrajudicial. Assim, havendo cláusula que estipule obrigação líquida, certa e exigível, é perfeitamente possível a propositura de execução judicial. Caso esse mesmo documento

\footnotetext{
${ }^{38}$ Segundo José Miguel Garcia Medina, em obra citada, "caso ainda não tenha sido constituído o órgão arbitral, pode a parte pleitear a medida de caráter antecedente ao órgão jurisdicional estatal que seria originariamente competente, que decidirá a respeito, produzindo efeitos tal pronunciamento até que se pronuncie o órgão arbitral". p. 468.

${ }^{39}$ CAHALI, F. J. Op. cit. p. 344-380.
} 
possua cláusula compromissória, e desde que a controvérsia não diga respeito à legalidade dessa cláusula, mas, sim, à exigibilidade do título oriundo da relação contratual, decidiu-se pela possibilidade de o credor executar judicialmente o contrato, isso porque o juízo arbitral é desprovido de poderes coercitivos.

Veja-se que "de acordo com orientação tradicionalmente reproduzida pela doutrina, o título executivo é a condição, estabelecida em lei, como necessária e suficiente para a realização da tutela jurisdicional executiva" ${ }^{40}$, eis que desnecessário averiguar judicialmente a "efetiva existência do direito que lhe é subjacente" 41 .

Assim, desde que o documento possua cláusula que contemple confissão de dívida líquida, certa e exigível, apta a constituir título executivo extrajudicial, não haveria qualquer óbice à execução desse título. Nesse sentido, destaca-se ementa da decisão ${ }^{42}$ paradigmática em tela, prolatada pela Ministra Nancy Andrighi:

PROCESSO CIVIL. POSSIBILIDADE DE EXECUÇÃO DE TÍTULO QUE CONTÉM CLÁUSULA COMPROMISSÓRIA. EXCEÇÃO DE PRÉEXECUTIVIDADE AFASTADA. CONDENAÇÃO EM HONORÁRIOS DEVIDA. - Deve-se admitir que a cláusula compromissória possa conviver com a natureza executiva do título. Não se exige que todas as controvérsias oriundas de um contrato sejam submetidas à solução arbitral. Ademais, não é razoável exigir que o credor seja obrigado a iniciar uma arbitragem para obter juízo de certeza sobre uma confissão de dívida que, no seu entender, já consta do título executivo. Além disso, é certo que o árbitro não tem poder coercitivo direto, não podendo impor, contra a vontade do devedor, restrições a seu patrimônio, como a penhora, e nem excussão forçada de seus bens. - São devidos honorários tanto na procedência quanto na improcedência da exceção de pré-executividade, desde que nesta última hipótese tenha se formado contraditório sobre a questão levantada. Recurso Especial improvido. (grifado)

Um dos fundamentos que consolidaram o entendimento acima foi no sentido de que não é razoável exigir-se do credor que inicie um procedimento arbitral para que seja atribuída certeza acerca de uma dívida que já está confessa em um título que possui eficácia executiva. Consoante exposto no voto condutor do julgado acima, "a efetividade dos direitos, princípio que sustenta o Estado Democrático, exige a simplificação das formas, bastando realmente iniciar a execução forçada".

\footnotetext{
${ }^{40}$ MEDINA, J.M. Op. cit. p. 1.046.

${ }^{41}$ CAHALI, F. J. Op. cit. p. 344-380.

42 STJ. REsp 944.917/SP, Rel. Ministra Nancy Andrighi, Terceira Turma, julgado em 18/9/2008, DJe de $3 / 10 / 2008$.
} 
A respeito do tema, destaca-se escólio de Luciano Benetti Timm ${ }^{43}$, segundo o qual o principal argumento para que seja possível a imediata propositura de processo executivo na situação em tela é que:

(...) o que foi objeto de cláusula compromissória são as disputas de mérito, ou seja, de fundo atinente ao negócio jurídico, ficando de fora direitos líquidos, certos e exigíveis de imediato e que não precisam ser instrumentalizados em decisão jurisdicional (privada). Ou dito de outro modo, o que foi objeto de cláusula arbitral foi o processo de conhecimento e não o processo de execução, que, como tal, seria irrenunciável (já que a coerção ainda é ato exclusivo do Estado).

Assim, uma vez que a cláusula contratual, que contempla direito líquido, certo e exigível, está contida em um título que possua eficácia de título executivo extrajudicial, nos termos do art.784, do CPC, por mais que esse título possua também uma cláusula arbitral para discussão de questões atinentes a controvérsias oriundas do negócio, é autorizada a imediata invocação do Poder Judiciário para que se promova a execução do título. Com isso, será possível a promoção, caso necessário, dos atos constritivos pertinentes à satisfação do direito reconhecido no título, assim como assegurados ao executado os meios de defesa processualmente garantidos.

Isso tudo porque, em suma, o título executivo extrajudicial prescinde de uma sentença arbitral condenatória que tenha por finalidade formar outro título a respeito da mesma dívida, eis que o título executivo extrajudicial já existe a partir do momento que preenche os requisitos legalmente previstos, razão porque torna-se viável a propositura de uma ação executiva desde logo perante o Poder Judiciário.

No que concerne a eventuais dúvidas a respeito do título em si ou das obrigações nele contidas, segundo Carlos Alberto Carmona "tal crise de certeza deve ser dirimida pela via arbitral; mas se houver inadimplemento, o credor socorrer-se-á desde lodo da via judicial, propondo demanda de execução, sem que haja espaço para a arbitragem"44. Com isso, verifica-se que é perfeitamente possível a coexistência da tutela executiva e de um procedimento arbitral de conhecimento, pois não são contraditórios, pelo contrário, se complementam, integrando a função jurisdicional ${ }^{45}$.

\footnotetext{
${ }^{43}$ Dos efeitos da convenção de arbitragem no processo de execução. Revista dos Tribunais On Line. p. 7. Revista de Arbitragem e Mediação| vol 31/2011|p.17-33| Out-Dez/2011; Doutrinas Essenciais Arbitragem e Mediação|vol.3/2014| p.1069-1089| Set/2014; DTR\2011\5126.

${ }^{44}$ Considerações sobre a cláusula compromissória e a cláusula de eleição de foro. In: --; Lemes, Selma Ferreira; Martins, Pedro Batista (coords.). Arbitragem: estudos em homenagem ao Prof. Guido Fernando da Silva Soares, in memoriam. São Paulo: Atlas, 2007.p.33-46.

45 TIMM, L. B. Op. cit. p. 8..
} 
Ademais, diante de uma execução fundada em título executivo extrajudicial que contenha cláusula arbitral, o executado não poderá discutir o mérito da questão por meio de embargos em razão do efeito negativo da convenção de arbitragem, o que torna o juízo estatal incompetente para o conhecimento dessas questões, sendo necessária a instauração de procedimento arbitral. Os embargos serão pertinentes, portanto, para a discussão tão somente de aspectos processuais executivos. 


\section{CONCLUSÃO}

A arbitragem é utilizada como método de resolução de conflitos desde os tempos mais remotos da civilização humana, eis que era comum confiar-se a um terceiro a decisão a respeito de determinados conflitos. Ao longo do desenvolvimento da sociedade, houve também o aprimoramento das técnicas de resolução de conflitos, chegando-se ao ponto no qual o Estado chamou para si tal responsabilidade, a qual denominou jurisdição.

Em que pese tenha-se consolidado o entendimento de que a jurisdição seria monopólio do Estado, concomitantemente a este, também desenvolveu-se a arbitragem, tendo nos tratados comerciais entre estados internacionais sua maior expressão. Assim, remonta ao início do século $\mathrm{XX}$ as discussões acerca da natureza jurídica da arbitragem, de modo que ainda hoje há quem entenda tratar-se de espécie de jurisdição, contrato, ambos ou instituto sui generis.

Nesse linha, tal discussão teve grande importância especialmente no que diz respeito à responsabilidade e à atuação do árbitro, e a eficácia da sentença arbitral. Houve momentos nos quais a sentença arbitral necessitaria passar pela homologação do Poder Judiciário para que surtisse efeitos entre as partes e, caso não houvesse seu cumprimento espontâneo, sujeitar-se-ia à execução perante o juízo estatal.

Embora a natureza jurídica da arbitragem ainda não esteja completamente consolidada, as discussões a esse respeito contribuíram para que houvesse importantes progressos nas regras atinentes ao procedimento arbitral, à atuação do árbitro e à sentença arbitral. Hoje, a função do árbitro é equiparada à função do juiz estatal, sendo considerado juiz arbitral; a sentença arbitral foi equiparada à sentença judicial, tratando-se de título executivo judicial, passível de execução direta junto ao juízo estatal que, na seara jurídica brasileira, ainda detém o poder de império para tanto.

Assim, não havendo o cumprimento espontâneo da sentença arbitral, tratando-se de sentença estrangeira, será executada segundo as leis do país onde fora prolatada, nos termos da legislação brasileira e da Convenção de Nova Iorque, da qual o Brasil é signatário; e caso seja uma sentença arbitral nacional, submeter-se-á ao procedimento de cumprimento de sentença, consoante dispõem a Lei da Arbitragem e o Código de Processo Civil. 
A questão controvertida apontada trata da possibilidade ou não de execução de título executivo que contenha cláusula arbitral, o que, em tese, poderia levar à discussão, em sede de embargos, do mérito da sentença arbitral.

Essa questão foi levada ao Poder Judiciário e, em decisão paradigmática, o Superior Tribunal de Justiça entendeu que na hipótese de um contrato conter cláusula com eficácia de título executivo extrajudicial, mas que também contenha cláusula arbitral para resolução de questões atinentes a controvérsias oriundas do negócio, é possível que o Poder Judiciário seja invocado para que se promova a execução do título com relação a essa cláusula que configura título executivo extrajudicial, com uma dívida líquida, certa e exigível.

A decisão foi nesse sentido em razão da desnecessidade de que seja prolatada uma sentença arbitral condenatória a respeito de uma cláusula que já possui eficácia de título executivo extrajudicial. Assim, tornar-se-á possível a realização de todos os atos oriundos a uma execução judicial, com a prática de atos constritivos pertinentes à satisfação do direito reconhecido no título, assim como assegura-se ao executado os meios de defesa legalmente garantidos, que, sob hipótese alguma, podem versar sobre o mérito do negócio, eis que analisável apenas na esfera arbitral. 


\section{REFERÊNCIAS}

BRASIL. Decreto $n^{\circ}$ 4.311, de 23 de julho de 2002. Promulga a Convenção sobre o Reconhecimento e a Execução de Sentenças Arbitrais Estrangeiras. D.O.U. de 24/07/2002 1997. Código de Processo Civil Comentado. 3a ed. São Paulo: Revista dos Tribunais,

Lei 9.307, de 23 de setembro de 1996. Dispõe sobre a arbitragem. D.O.U. de 24/09/1996.

. STJ. REsp 944.917/SP. Rel. Ministra Nancy Andrighi, Terceira Turma, julgado em 18/9/2008, DJe de 3/10/2008.

BARROCAS, Manuel Pereira. Manual de Arbitragem. Coimbra: Editora Almedina. 2010.

CAHALI, Francisco José. Curso de Arbitragem. 5a ed. rev. e atual., de acordo com a Lei 13.129/2015, com a Lei 13.140/2015 e o Novo CPC. São Paulo: Editora Revista dos Tribunais. 2015.

CARMONA, Carlos Alberto. Arbitragem e jurisdição. Revista dos Tribunais On Line. p. 1. Revista de Processo | vol. 58 |p. 33 - 40 | Abr - Jun / 1990. Doutrinas Essenciais Arbitragem e Mediação | vol. 1 | p. 833 - 844 | Set / 2014. DTR\1990\55.

Considerações sobre a cláusula compromissória e a cláusula de eleição de foro. In: --; Lemes, Selma Ferreira; Martins, Pedro Batista (coords.). Arbitragem: estudos em homenagem ao Prof. Guido Fernando da Silva Soares, in memoriam. São Paulo: Atlas, 2007.

DIDIER JR, Fredie. Curso de Direito Processual Civil: teoria geral do processo e processo de conhecimento. 13a ed. v.1. Bahia: Editora JusPodivm, 2010.

DINAMARCO, Cândido Rangel. A arbitragem na teoria geral do processo. São Paulo: Editora Malheiros. 2013.

. LOPES, Bruno Vasconcelos Carrilho. Teoria geral do novo processo civil. São Paulo: Editora Malheiros. 2016.

A instrumentalidade do processo. São Paulo: Editora Malheiros. 2013.

FIGUEIRA JUNIOR, Joel Dias. Arbitragem (legislação nacional e estrangeira) e o monopólio jurisdicional. São Paulo: LTr, 1999.

LEW, Julian D.M. MISTELIS, Loukas A. KROL, Stefan M. Comparative International Commercial Arbitration. Klwer Law International: Netherlands, 2003.

MARINONI, Luiz Guilherme. Rápidas observações sobre arbitragem e jurisdição. 2014. p.14-24. Disponível em <https://processoemdebate.files.wordpress.com/2010/09/arbitrageme-jurisdicao_marinoni.pdf>. Acesso em 15 de agosto de 2016.

'Revista de Cidadania e Acesso à Justiça | e-ISSN: 2526-026X | Curitiba | v. 1 | n. 2 | p. 789 - 809 | Jul/Dez. 2016. 
NERY JR, Nelson. Código de Processo Civil Comentado. 3a ed. São Paulo: Revista dos Tribunais, 1997.

THEODORO Jr. Humberto. Curso de Direito Processual Civil. Rio de Janeiro: Forense, v. III, 2005.

TIMM, Luciano Benetti. Dos efeitos da convenção de arbitragem no processo de execução. Revista dos Tribunais On Line. p. 8. Revista de Arbitragem e Mediação| vol 31/2011|p.17-33| Out-Dez/2011; Doutrinas Essenciais Arbitragem e Mediação|vol.3/2014| p.1069-1089| Set/2014; DTR\2011\5126. 